\title{
THE PRODUCTION AND IDENTIFICATION OF ANTIBODIES TO INSULIN AND THEIR USE IN ASSAYING INSULIN ${ }^{1}$
}

\author{
BY EDWARD R. ARQUILLA AND ABRAM B. STAVITSKY \\ (From the Departments of Anatomy and Microbiology, School of Medicine, Western Reserve \\ University, Cleveland, Ohio)
}

(Submitted for publication November 22, 1954; accepted December 28, 1955)

A specific method for the detection of small quantities of insulin in body tissues and fluids might help to resolve some of the problems connected with the mechanism of action and hormonal interrelationships of insulin. The biological assay methods for small quantities of insulin (2-4) are based upon the effect of insulin on glucose metabolism. Although very sensitive, these methods have several disadvantages. They are technically difficult, are dependent upon the physiological effect of insulin, therefore, subject to considerable biological variation, and consequently may not be specific for insulin per se. A method specific for insulin and independent of biological variation would, therefore, be highly desirable.

Since serological methods are highly specific and independent of biological variation, an immunological approach to the measurement of insulin in tissues and body fluids appeared promising. Moreover, it has been noted here and in other laboratories $(5-8)$ that the hemagglutination technique employing tannic acid and protein treated red cells is highly specific and also very sensitive. It was suggested (8), however, that greater precision in the measurement of antigen could be attained by converting the hemagglutination to a hemolytic reaction with the addition of complement. In this way the reaction could be measured colorimetrically. This conversion was impossible with tannic acid-treated cells since they often are lyzed in the presence of complement alone $(7,9)$. Consequently other methods of coupling protein to red cells were sought. The method using bis-diazotized benzidine, as described by Pressman, Campbell, and Pauling (10), has been modified and was used in the present study.

The antigenicity of insulin has been indicated by several investigators (11-15). Barral and

1 A preliminary report of this work was presented before the American Association of Immunologists at Chicago in the Spring of 1953 (1). This study was supported in part by a grant from Eli Lilly and Company.
Roux (11) and later Bernstein, Kirsner, and Turner (12) elicited anaphylactic responses to insulin in guinea pigs. Lewis (13) observed the Schultz-Dale reaction in uteri of guinea pigs sensitized with insulin. By the use of the complement fixation, Wasserman, Broh-Kahn, and Mirsky (14) were able to demonstrate antibodies to insulin in six of eleven immunized rabbits. Lowell and Franklin (15) induced resistance to the hypoglycemic action of insulin in four of twentyfour rabbits by repeated injections of insulin.

Evidence is presented here that antibodies to insulin can be produced consistently in rabbits. These antibodies, as well as antibodies in patients resistant to insulin, can be detected by hemagglutination and hemolysis of insulin-conjugated erythrocytes. Methods are also presented for the assay of microgram quantities of insulin in pure solutions. Evidence that rabbit anti-insulin serum is specific for insulin, and that there is a high degree of serological cross-reactivity among insulins from various species is presented in the next paper (16).

\section{MATERIALS ${ }^{2}$ AND METHODS}

The preparation of bis-diazo-benzidine. Bis-diazobenzidine (BDB) was prepared according to the method of Kabat and Mayer (17). It was essential to maintain the temperature of the reaction mixture below $0^{\circ} \mathrm{C}$. The final product was a pale yellow solution. It could be stored for an indefinite period of time if frozen at $-80^{\circ} \mathrm{C}$ and maintained at $-35^{\circ} \mathrm{C}$ to $-40^{\circ} \mathrm{C}$.

Normal rabbit serum. Normal rabbit serum (NRS) was prepared by heating serum from non-immunized rabbits at $56^{\circ} \mathrm{C}$ for 30 minutes and absorbed with an equal volume of washed, packed sheep erythrocytes for 15 minutes at room temperature. Normal rabbit serum diluted 100 times $(1 / 100 \mathrm{NRS})$ was used as the diluent in the hemagglutination titrations.

Erythrocyte preparations.2 Either sheep or rabbit blood diluted with Alsever's solution (18) was used as the source of erythrocytes. The blood was not used for

2 The authors wish to thank the Eli Lilly Co. for the various preparations of insulin. 
more than one week and was kept at $5^{\circ} \mathrm{C}$ while not in use.

Complement preparations. Dried or fresh frozen guinea pig serum was used as the source of complement. All dilutions of complement were made with 0.9 per cent saline. Fresh guinea pig serum was separated from clotted blood within four to five hours after bleeding. The clot was allowed to shrink at room temperature. The serum was quick frozen at $-80^{\circ} \mathrm{C}$ in an alcohol-dry ice bath and stored at $-35^{\circ}$ to $-40^{\circ} \mathrm{C}$. Fresh frozen guinea pig serum treated in this manner, retained full hemolytic activity for at least six months.

Isotonic phosphate buffer. One part of $0.219 \mathrm{M}$ $\mathrm{Na}_{2} \mathrm{HPO}_{4}$ was added to four parts of $0.219 \mathrm{M} \mathrm{NaH}_{2} \mathrm{PO}_{4}$ to make up a stock solution of ionic strength of 0.3 (twice isotonicity) at $\mathrm{pH}$ between 7.35 to 7.4. This stock phosphate buffer was diluted with an equal volume of $\mathrm{H}_{2} \mathrm{O}$ to prepare isotonic phosphate buffer.

Insulin preparations. The insulin used in these experiments was derived from either of two lots: Lot No. 535664 or Lot No. 466368 . Lot No. 535664 consisted of a preparation of zinc crystalline beef insulin which assayed 27 units per milligram. Lot No. 466368 represented a special trypsin-treated insulin prepared from beef. It probably contained small amounts of trypsin and possibly some other proteins; however, it was free of glucagon (hyperglycemic factor) activity.

The insulin was dissolved in a small volume of $0.005 \mathrm{~N}$ $\mathrm{NaOH}$ and then diluted to the desired volume with isotonic phosphate buffer, $\mathrm{pH} 7.35$ to 7.4. All stock solutions contained one milligram per milliliter. The solutions were stored at $5^{\circ} \mathrm{C}$ when not in use. No insulin solutions were used after three days from the time they were prepared.

Immunization. The antigen was prepared by suspending $50 \mathrm{mg}$. of crystalline zinc insulin in $10 \mathrm{ml}$. of saline to which was added $0.5 \mathrm{ml}$. of 1 per cent alum ( $\mathrm{KAlSO}_{4}$ ). Enough $1 \mathrm{~N} \mathrm{NaOH}$ was then added to the preparation to make it just faintly acid to hydronium ion paper.

Adult white rabbits of either sex weighing between 3 and 4 kilograms were injected in the marginal ear vein with alum-precipitated insulin. In order to prevent hypoglycemia, $25 \mathrm{ml}$. of 40 per cent glucose was given subcutaneously in the nape of the neck immediately following the insulin injection.

All of the collected sera were inactivated at $56^{\circ} \mathrm{C}$ for 30 minutes and then absorbed with an equal volume of washed, packed sheep erythrocytes. These rabbit antisera were stored at $-35^{\circ} \mathrm{C}$ until they were tested.

Preparation of insulin conjugated erythrocytes. A mixture of saline and insulin solution ( $1 \mathrm{mg}$. in $1 \mathrm{ml}$.) was prepared by adding $1.2 \mathrm{ml}$. of saline to $2.4 \mathrm{ml}$. of insulin solution. To this mixture, $0.05 \mathrm{ml}$. of washed packed sheep or rabbit erythrocytes were added. One-half milliliter of BDB, diluted $1 / 15$ with isotonic phosphate buffer $\mathrm{pH} 7.4$, was then added to this cell suspension. With the addition of the phosphate buffer the BDB turned from a pale yellow to a deep reddish-brown. The suspension of cells, saline, insulin, and BDB was then gently mixed, allowed to stand at room temperature for ten minutes, and centrifuged at $1700 \mathrm{rpm}$ for five minutes. The supernatant was decanted, and the cells were suspended in $3.5 \mathrm{ml}$. of 1/100 NRS. The insulin sensitized cells were then re-centrifuged at $1700 \mathrm{rpm}$, the supernatant again decanted, and the cells resuspended in $2.5 \mathrm{ml}$. of $1 / 100$ NRS.

There was no hemoglobin in these supernatants. Microscopically the cells appeared as bi-concave discs; no ghosts or evidence of agglutination could be observed. The insulin sensitized BDB erythrocytes could be used for hemagglutination and hemolytic reactions for a period of at least five hours after preparation.

It was necessary to determine the optimal ratio of BDB to insulin for the sensitization of the erythrocytes. When excess insulin was used, the cells were not agglutinated by the insulin antisera. If too little insulin was used, agglutination and lysis occurred after the addition of BDB to the cell suspension. The ratio of BDB to protein used in sensitizing the red cells was dependent upon the particular protein involved (19). There was little variation of this ratio, however, when different batches of BDB were used with the same protein.

Preservatives, such as phenols, and amino acids such as glycine, when present in the reaction mixture may interfere with the conjugation of protein to the red cell surface (19). It is believed that such compounds react with BDB and thereby prevent the conjugation of protein to the erythrocyte surface by BDB (19).

The detection of insulin antibodies by hemagglutination. Two series of doubling dilutions of each test antiserum ranging from $1 / 10$ to $1 / 5120$ were prepared in $10 \times 75$ $\mathrm{mm}$. test tubes, with $1 / 100 \mathrm{NRS}$ as the diluent in a final volume of $0.5 \mathrm{ml}$. To the experimental series $10 \mu \mathrm{g}$. of insulin in $0.1 \mathrm{ml}$. was added to each test tube and to the controls $0.1 \mathrm{ml}$. of saline was added to each test tube. After mixing, $0.05 \mathrm{ml}$. of insulin conjugated erythrocytes was added to all the test tubes, thus making a final volume of $0.65 \mathrm{ml}$. Controls containing $0.05 \mathrm{ml}$. of a 2 per cent suspension of washed, unsensitized erythrocytes and $0.6 \mathrm{ml}$. of a 1/10 dilution of antiserum were run in duplicate at all times. All tubes were shaken in order to disperse the cells evenly and allowed to stand for 3 to 4 hours. Precautions were taken not to disturb the cells while they were settling.

Agglutination was determined by the pattern of sensitized erythrocytes at the bottom of the tube. In the absence of agglutination, a discrete button of red cells was observed. Slight agglutination resulted in the formation of a halo surrounding a central film. Positive agglutination resulted in an evenly distributed sheet of erythrocytes. When agglutination was maximal, this sheet was wrinkled and folded. It is important that the test tubes used $(10 \times 75 \mathrm{~mm}$.) be uniform and that they do not have distorted bottoms. A detailed description and photograph of these reactions has been presented elsewhere (7). Arbitrary criteria for the presence of antibodies were established as follows:

1. The agglutination of insulin-sensitized erythrocytes by the test antiserum. 
2. Agglutination was inhibited when the test antiserum was preincubated with crystalline insulin.

3. The absence of agglutination of non-sensitized erythrocytes by the test antiserum.

The titre of any given insulin antiserum was designated as the highest dilution in which there was definite evidence that agglutination had taken place.

The hemolytic titration of insulin antiserum. As in the agglutination titration, serial dilutions of antiserum were prepared in duplicate. To one series was added insulin (10 rg. in $0.1 \mathrm{ml}$.) and to the second, saline. These serial dilutions were cooled to $0^{\circ} \mathrm{C}$ in an ice bath, and $0.5 \mathrm{ml}$. of $1 / 10$ guinea pig serum, diluted with saline, was added, thus increasing the volume to $1.1 \mathrm{ml}$. To each tube $0.15 \mathrm{ml}$. of insulin-conjugated erythrocytes was then added, bringing the final volume to $1.25 \mathrm{ml}$. The cells were then evenly dispersed by shaking, incubated at $37^{\circ} \mathrm{C}$ for 30 minutes, centrifuged at $1700 \mathrm{rpm}$ for 10 minutes and the supernatant decanted and saved. The relative amounts of hemoglobin released into the supernatants were measured quantitatively with the Beckman spectrophotometer at a wave length of $576 \mathrm{~m} \mu$. The Lowry and Bessey microadaptation (20) of the Beckman spectrophotometer was used. All of the samples were read against water. The magnitude of the blank from non-specific hemolysis varied with different batches of complement. No corrections for this non-specific hemolysis were made in this study. However, it was subsequently learned that the non-specific hemolysis could be reduced considerably if the guinea pig serum was previously absorbed with sheep erythrocytes, as described in the following paper (16).

TABLE I

The appearance of antibodies to insulin in adult white rabbits

\begin{tabular}{|c|c|c|c|c|c|}
\hline \multirow[b]{2}{*}{$\begin{array}{l}\text { Rabbit } \\
\text { No. }\end{array}$} & \multirow{2}{*}{$\begin{array}{l}\text { No. of } \\
\text { injections } \\
\text { of alum- } \\
\text { precipi- } \\
\text { tated } \\
\text { insulin }\end{array}$} & \multirow[b]{2}{*}{$\begin{array}{l}\text { Volume } \\
\text { of each } \\
\text { injection } \\
\text { ml.* }\end{array}$} & \multicolumn{2}{|c|}{$\begin{array}{l}\text { No. of days before } \\
\text { appearance of } \\
\text { antibodies to } \\
\text { insulin }\end{array}$} & \multirow[b]{2}{*}{$\begin{array}{c}\text { First } \\
\text { observed } \\
\text { titre of } \\
\text { antiserum }\end{array}$} \\
\hline & & & $\begin{array}{c}\text { After } \\
\text { first } \\
\text { injection }\end{array}$ & $\begin{array}{c}\text { After } \\
\text { last } \\
\text { injection }\end{array}$ & \\
\hline $\begin{array}{l}R-1 \\
R-2 \\
R-3 \\
R-9 \\
R-10 \\
R-13 \\
R-14 \\
R-15 \\
R-18 \\
4 \text { N } 3 \\
4 \text { M O } \\
\text { A-1 } \\
\text { A-2 } \\
\text { A-3 } \\
\text { A-4 } \\
\text { A-5 } \\
A-6\end{array}$ & $\begin{array}{r}5 \\
5 \\
5 \\
7 \\
9 \\
3 \\
6 \\
5 \\
10 \\
9 \\
8 \\
6 \\
7 \\
7 \\
7 \\
7 \\
9\end{array}$ & $\begin{array}{l}0.2 \\
0.2 \\
0.2 \\
0.3 \\
0.3 \\
0.5 \\
0.5 \\
0.5 \\
0.5 \\
0.5 \\
0.5 \\
0.5 \\
0.5 \\
0.5 \\
0.5 \\
0.5 \\
0.5\end{array}$ & $\begin{array}{r}19 \\
19 \\
19 \\
14 \\
61 \\
8 \\
16 \\
11 \\
130 \\
131 \\
131 \\
126 \\
66 \\
64 \\
66 \\
202 \\
202\end{array}$ & $\begin{array}{rl}9 \\
9 \\
9 \\
2 \\
8 & 19 \dagger \\
2 & \\
3 \\
3 \\
2 \\
2 \\
3 \\
96 \\
10 \\
8 \\
10 \\
7 \\
7\end{array}$ & $\begin{array}{ll}1 & 80 \\
0 & \\
0 & \\
0 & \\
0 & \\
0 & \\
1 & 320 \\
1 & 40 \\
1 & 640 \\
1 & 160 \\
1 & 20 \\
1 & 40 \\
1 & 20 \\
1 & 640 \\
1 & 160 \\
1 & 1280 \\
1 & 160\end{array}$ \\
\hline
\end{tabular}

* Each ml. of alum-precipitated insulin contained $5 \mathrm{mg}$. of insulin. Prior to immunization the anti-insulin titre in all rabbits was zero.

t R-10 was tested both 8 and 19 days after the last injection-on both of these occasions the serum titre was 0 .
When the concentration of hemoglobin was plotted against the antiserum dilutions, two curves were obtained (Figure 2); one corresponding to the dilutions of antiserum with which saline was preincubated, and the other to those where $10 \mu \mathrm{g}$. of insulin was preincubated. Consequently it was possible to estimate the degree of inhibition of lysis of insulin-sensitized erythrocytes at any given dilution of antiserum. This information was essential in determining the dilution of antiserum required in running a standard curve for assaying insulin as described in a later section on the insulin assay.

Ring and precipitin reactions. The ring reaction was performed as described by Boyd (21). Various concentrations of insulin in buffer were carefully laid over the antiserum in a capillary tube. The tubes were kept at room temperature for 12 to 24 hours, and observed for the appearance of an interphasic precipitate.

The precipitin reaction was carried out in $10 \times 100 \mathrm{~mm}$. glass tubes. One-tenth milliliter of varying concentrations of insulin was mixed with $0.1 \mathrm{ml}$. antiserum and $0.1 \mathrm{ml}$. of saline. The tubes were then incubated at $37^{\circ} \mathrm{C}$ for 1 and $1 / 2$ hours and placed in the refrigerator overnight, and observed for the appearance of turbidity or precipitate.

\section{RESULTS}

\section{Characteristics of rabbit antibodies to insulin}

The production of insulin antibodies required a minimal dose of antigen $(2.5 \mathrm{mg}$. of alum-precipitated insulin in $0.5 \mathrm{ml}$.) given 6 to 10 times for a period varying from 16 to 202 days. In Table I, the first five animals received a dose of less than $0.5 \mathrm{ml}$. (2.5 mg.) of alum-precipitated insulin per injection. Only one of these animals produced antibodies. The remaining twelve animals received $0.5 \mathrm{ml}$. (2.5 mg.) of an alum-precipitated insulin per injection. Eleven of these animals developed antibodies to insulin. The one animal which did not, died following the third injection. In the eleven animals which produced antibodies to insulin, a minimum of 5 and a maximum of 10 injections were required.

In the majority of animals the antibodies to insulin appeared approximately 2 to 6 months after the first injection of antigen. It is possible that antibodies not detectable by the methods employed may have been produced sooner.

Since a large amount of glucose was administered following each injection of antigen, the injections were spread over a period of two to three months. In this way, the rabbits were exposed to less trauma per unit time, and the risk of infection was decreased. 
A specific anamnestic response was observed in all rabbits which had previously developed antibodies. In two animals a single injection of alumprecipitated insulin was followed by a rise of the anti-insulin titre to a peak in seven to nine days (Figure 1). The antibody titre then decreased to $1 / 10$ within 4 months. Alum-precipitated insulin injected at subsequent intervals of two months elicited progressively higher anti-insulin titres. This occurred despite the fact that the anti-insulin titre had returned to very low levels before each of the subsequent injections (Figure 1).

It appears, therefore, that repeated intravenous injections of adequate amounts of alum-precipitated insulin over a sufficiently long period of time can consistently elicit antibodies to insulin in the rabbit.

It was possible to separate the antibodies from the remaining serum proteins by the method of Nicol and Deutsch (22), in which the antibodyrich gamma globulin fraction plus some traces of beta globulin are precipitated from a diluted serum. Seventy per cent of the antibody activity was recovered in the gamma globulin fraction which represented about 10 per cent of the total serum proteins.

\section{Ring and precipitin reactions}

Rabbit antiserum (4 MO.) which had a titre of $1 / 80,000$, and other lowered titred sera were studied. The concentration of crystalline beef insulin employed ranged from 38 to 300 micrograms per milliliter. It was realized that even 38 micrograms might constitute excess antigen for these antisera

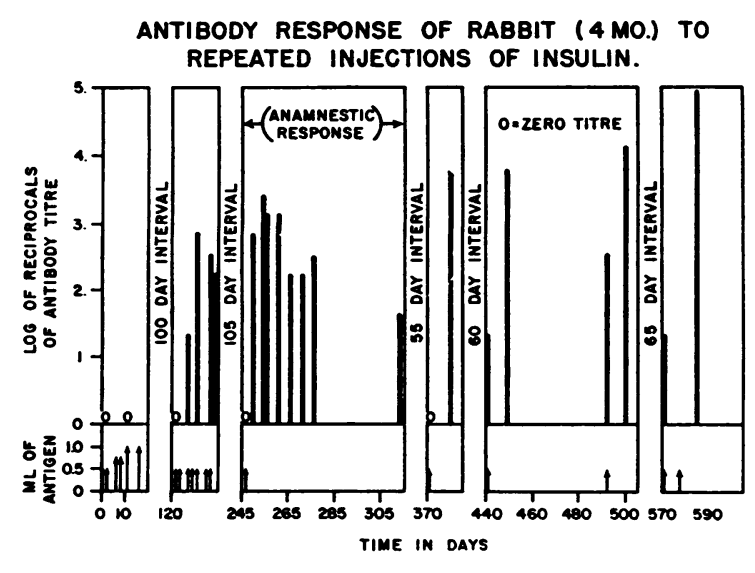

Figure 1
SPECIFIC INHIBITION OF LYSIS

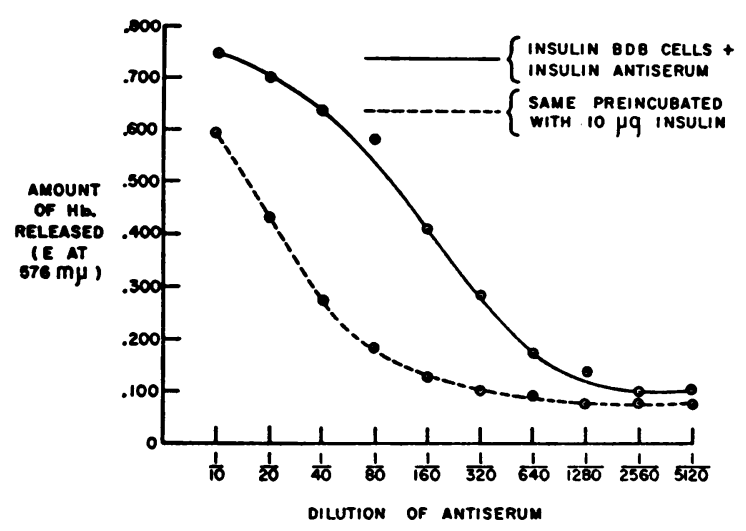

Figure 2

and soluble, undetectable antigen-antibody complexes might result. However, insufficient antiserum was available for a more systematic study of the precipitability of these antisera with smaller amounts of antigen. All reactions were negative.

\section{Attempts to produce skin sensitivity to insulin}

Franklin and Lowell (23) produced skin sensitivity to insulin in intensively immunized rabbits. A number of rabbits possessing high hemagglutination titres $(1 / 640$ to $1 / 80,000)$ were injected intradermally with 20 micrograms of insulin. Other normal rabbits were injected in several sites with $0.1 \mathrm{ml}$. of antiserum $4 \mathrm{MO}$. (titre $1 / 80,000$ ). Twenty-four hours later, these same areas were injected with insulin (20 to 100 micrograms). As controls in both actively and passively immunized rabbits, equivalent concentrations of bovine gamma globulin were injected into other skin sites previously infiltrated with the anti-insulin serum. All reactions were negative.

\section{The detection of insulin antibodies in diabetic patients}

The results presented in Table II were obtained by using insulin-sensitized rabbit erythrocytes. The insulin-sensitized rabbit erythrocytes were used because they were agglutinated at higher dilutions of antiserum than the insulin sensitized sheep erythrocytes (19).

The sera of 23 diabetic patients were tested by the hemagglutination technique for insulin antibodies. The sera of eleven of the 23 diabetics contained antibodies to insulin. Seven patients re- 
TABLE II

Antibodies to insulin in diabetic patients *

\begin{tabular}{|c|c|c|c|c|}
\hline Patients & $\begin{array}{c}\text { Insulin } \\
\text { require- } \\
\text { ment } \\
U \text { nits/day }\end{array}$ & $\begin{array}{c}\text { Antibody } \\
\text { titre }\end{array}$ & $\begin{array}{c}\text { Titre } \\
\text { after } \\
\text { inhibition } \\
\text { with 10 } \\
\text { insulin. }\end{array}$ & Comments \\
\hline $\begin{array}{l}\text { Ber. } \\
\text { R. S. } \\
\text { Weil. } \\
\text { Hen. } \\
\text { O. S. } \\
\text { O. H. } \\
\text { J. G. } \\
\text { D. S. } \\
\text { B. B. } \\
\text { Sed. } \\
\text { Cug. }\end{array}$ & $\begin{array}{r}2,000 \\
2,000 \\
600 \\
500 \\
500 \\
125 \\
120 \\
90 \\
85 \\
70 \\
40\end{array}$ & $\begin{array}{l}1 / 160 \\
1 / 64 \\
1 / 1280 \\
1 / 32 \\
1 / 64 \\
1 / 160 \\
1 / 128 \\
1 / 128 \\
1 / 40 \\
1 / 12 \\
1 / 160\end{array}$ & $\begin{array}{l}0 \\
1 / 8 \\
1 / 20 \\
1 / 4 \\
1 / 16 \\
1 / 20 \\
1 / 16 \\
1 / 16 \\
0 \\
1 / 3 \\
1 / 10\end{array}$ & $\begin{array}{l}\text { Patients whose } \\
\text { sera contained } \\
\text { antibodies to } \\
\text { insulin. }\end{array}$ \\
\hline $\begin{array}{l}\text { A. S. } \\
\text { J. D. } \\
\text { D. R. }\end{array}$ & $\begin{array}{c}\text { Diet only } \\
40 \\
65\end{array}$ & $\begin{array}{l}1 / 32 \\
1 / 16 \\
1 / 16\end{array}$ & $\begin{array}{l}1 / 16 \\
1 / 8 \\
1 / 8\end{array}$ & $\begin{array}{l}\text { Patients with } \\
\text { questionable } \\
\text { presence of } \\
\text { antibodies. }\end{array}$ \\
\hline $\begin{array}{l}\text { L.S. } \\
\text { A. C. } \\
\text { H.S. } \\
\text { N. F. } \\
\text { Wil. } \\
\text { H.S. } \\
\text { W. J. } \\
\text { Bur. } \\
\text { Jef. }\end{array}$ & $\begin{array}{l}100 \\
45 \\
40 \\
25 \\
5 \\
\text { Diet only } \\
\text { No insulin } \\
\text { No insulin } \\
\text { New diabetic }\end{array}$ & $\begin{array}{c}0 \\
0 \\
0 \\
0 \\
1 / 8 \\
0 \\
0 \\
0 \\
0\end{array}$ & $\begin{array}{c}0 \\
0 \\
0 \\
0 \\
1 / 8 \\
0 \\
0 \\
0 \\
0\end{array}$ & $\begin{array}{l}\text { Patients whose } \\
\text { sera did not } \\
\text { contain anti- } \\
\text { bodies to } \\
\text { insulin. }\end{array}$ \\
\hline
\end{tabular}

* The authors wish to thank the following persons who graciously made available the sera of the diabetic patients: Dr. James Craig of the Department of Medicine, Western Reserve University, Cleveland, Ohio; Dr. E. Perry McCullagh, Cleveland Clinic; Dr. Mary Loveless, N. Y. Hospital, New York City; Dr. Bernard Charms of Mount Sinai Hospital, Cleveland, Ohio.

ceived 120 to 2000 units of insulin per day. Antibodies to insulin were found in the sera of each of these seven patients. Four other patients who had antibodies to insulin received 70 to 90 units of insulin per day. Antibodies to insulin were not detected in nine of the patients. Four of these had never received insulin. One patient in whom antibodies were not detected received 100 units of insulin per day. The presence of antibodies in the sera of the remaining three patients was questionable.

\section{Insulin assay}

Where a semi-quantitative and rapid estimate of insulin content was desired, the hemagglutination method was used. ${ }^{3}$ Known amounts of insulin

3 This method has been used previously in this laboratory (8) for determining the concentration of egg albumin in egg white and the amount of diphtheria toxin or toxoid remaining in the supernatant in the quantitative flocculation reaction with antitoxin. were preincubated with each of several serial dilutions of a single insulin antiserum. In the control, saline was preincubated with identical dilutions of the same antiserum. The methods and materials used in this case were the same as described for the hemagglutination titration of an antiserum earlier in this paper.

The antiserum titre was decreased as increasing amounts of insulin were preincubated with the antiserum. Because this method was only semiquantitative and the end point of agglutination was to a large extent subjective, the parameters of the method were not investigated thoroughly.

Therefore, it was decided to investigate an immune hemolysis method for assaying insulin. It was found that the amount of lysis of insulinsensitized erythrocytes by a given dilution of antiserum varied inversely as the logarithm of the amount of insulin preincubated with the antiserum (Figure 3).

The methods and materials including final volume used in the hemolytic assay were the same as in the hemolytic titration as described earlier in this paper. The dilution of any given antiserum used in the assay was determined first by doing a hemolytic titration (Figure 2). Those dilutions where the inhibition of lysis of insulin-sensitized cells was maximal when $10 \mu \mathrm{g}$. of insulin was preincubated with the antiserum, were used in establishing standard curves for the antiserum involved (Figure 2). Various amounts of insulin in equal volumes $(0.1 \mathrm{ml}$.) were preincubated with a given dilution of antiserum prior to the addition of complement and insulin-sensitized erythrocytes. The amount of hemoglobin released into the super-

STANDARD CURVES FOR INSULIN ASSAY

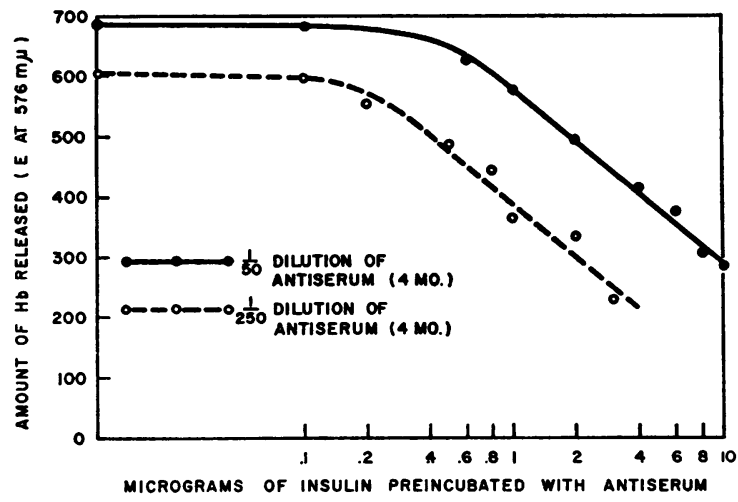

Figure 3 
natant (within certain limits) diminished as a straight line function of the log of the amount of insulin preincubated (Figure 3 ). As the dilution of antiserum was increased, the standard curve shifted to the left. Consequently, the sensitivity of the method was dependent upon the dilution of the antiserum.

In Figure 3, typical standard curves of fifty times and two hundred fifty times diluted insulin antiserum are presented. When 1 to $10 \mu \mathrm{g}$. of insulin were preincubated with the $1 / 50$ (rabbit 4 MO.) antiserum, the inhibition of lysis of insulinsensitized erythrocytes was linear. When 0.2 to $5 \mu \mathrm{g}$. of insulin were preincubated with the same antiserum diluted $1 / 250$, the curve was also linear. Samples containing between 1 and $10 \mu \mathrm{g}$. of insulin in $0.1 \mathrm{ml}$. were assayed using the fifty times diluted antiserum. Those containing below a microgram of insulin were assayed with $1 / 250$ dilution of antiserum. There was about a fifteen per cent error when duplicates of the same point of the standard curve were run.

Complement was used in excess $(0.5 \mathrm{ml}$. of $1 / 10$ guinea pig serum) so that the amount of antibody not bound by insulin during preincubation and hence available for hemolysis was the only limiting factor. The factors limiting the sensitivity of the assay are discussed below. Thus far the assay has been applied only to the measurement of insulin in solution.

\section{DISCUSSION}

Previous evidence (12-15) indicates that insulin is weakly antigenic. By use of serological methods antibodies to insulin could not be demonstrated in all immunized animals. Even by use of highly sensitive methods such as anaphylaxis (24) insulin antibodies have not been detected in all immunized animals. Nor have insulin antibodies been demonstrated in all insulin-resistant diabetics (25). 4

Borduas and Grabar (6) and Stavitsky (7) have presented evidence for the superior sensitivity of the hemagglutination compared to other

\footnotetext{
- Since the completion of this study Moloney and Coval (26) have presented new evidence for the antigenicity of insulin. Insulin-neutralizing antibodies for insulin were induced in guinea pigs and in sheep by injections of insulin in Freund's adjuvant. Mice were rendered diabetic by injection of guinea pig anti-insulin serum.
}

serological and immunological methods. With these techniques insulin antibodies were demonstrated in virtually every immunized animal and in seven patients requiring 120 to 2000 units of insulin daily.

The sera of rabbits immunized with alum-precipitated crystalline beef insulin exhibited many properties of in vivo and in vitro antigen-antibody reactions. These antisera agglutinated insulinconjugated rabbit or sheep erythrocytes. This agglutination was inhibited by preincubation of insulin with these antisera. The insulin antisera did not agglutinate non-sensitized sheep or rabbit erythrocytes. The antiserum lyzed insulin-sensitized red cells in the presence of complement. This hemolysis was inhibited by preincubation of insulin with the antiserum. The insulin antibodies were found in the gamma globulin fraction of the rabbit serum. ${ }^{5}$ An anamnestic response to a single injection of insulin was elicited in rabbits which were previously immunized. In the next paper (16) data are presented concerning the serological cross-reactivity of insulins from various species, the neutralization of the physiological effects of insulin, and the specificity of the insulin antibodies produced in the rabbit.

The failure to observe ring and precipitin reactions with the sera of intensively immunized rabbits may be explained in one or two ways. First, the antibodies may not have been present in amounts sufficient to form visible aggregates with the amounts ( 38 to 300 micrograms) of antigen employed. This is a good possibility since even 38 micrograms may constitute a large excess of antigen for all but potent antisera. Therefore, when larger amounts of serum are available they should be tested for precipitins with amounts of insulin from 0.1 to 2 or 3 micrograms using $1 \mathrm{ml}$. samples of serum, and allowing the tests to remain in the refrigerator for a week before centrifuging and reading. The second possibility is that there may have been produced antibodies of a type which could be detected by the hemagglutination and hemolytic but not by the ring and precipi-

S Since the completion of this study Sehon, Kaye, McGarry, and Rose (27) by zone electrophoresis have isolated an insulin-neutralizing factor in the gamma globulin fraction of the serum of an insulin-resistant patient. They did not observe precipitin reactions between this serum or fraction and insulin. 
tation methods. This is considered unlikely since it has been found (19) that non-precipitating antibodies do not hemagglutinate red cells treated with the homologous protein.

In view of the ability to demonstrate insulin antibodies in immunized rabbits and insulin-resistant diabetics, it is important to learn whether these antibodies affect the physiological action of endogenous or injected insulin. Berne and Wallerstein (25) have reviewed the work from many laboratories and concluded that the presence or absence of antibodies in insulin-allergic or insulin-resistant patients was not correlated with the degree of allergic response or resistance to insulin. However, insulin-neutralizing substances have been demonstrated in the serum of insulin-resistant patients and immunized rabbits. Lowell (28) using the blood sugar curve method in mice, has shown the presence of insulinneutralizing substances in the blood of insulin-resistant diabetics. Recently, Marsh and Haugaard (29) observed a significant decrease in the amount of insulin that combined with a diaphragm preparation when the insulin was preincubated with sera from normal diabetic patients. They attributed this to substances in serum which combine with or inactivate insulin. Serum from insulin-resistant patients contained greatly increased amounts of these substances compared to normal, and non-resistant diabetics. We have evidence (16) indicating that the serum of insulin-immunized rabbits can neutralize the physiological effects of insulin as tested by the mouse convulsion method.

It may be significant that all seven patients who required between 120 and 2,000 units of insulin per day had antibodies to insulin. However, it is not known whether the presence of antibodies accounted for the high daily requirement or whether the antibodies resulted from the daily injection of large amounts of insulin.

The hemagglutination method may facilitate the study of the immunological aspects of insulin resistance. However, it is probable that only antibodies uncombined with insulin can be detected. Therefore, in patients exhibiting low titres it may be necessary to withdraw insulin for several days before antibodies become apparent.

With the hemagglutination and hemolytic methods it has been possible to detect 0.1 microgram of insulin in solution. It is felt that with further work, the assay can be made more sensitive. The biological methods have been able to detect as little as 0.001 microgram of insulin.

Anderson, Linder, and Sutton (2) was able to measure 0.02 milliunits (about $0.001 \mu \mathrm{g}$.) using adrenal demedullated, alloxan diabetic, hypophysectomized rats. Bornstein (3) using hypophysectomized, alloxan diabetic, and adrenalectomized rats has been able to detect 0.05 milliunits (about $0.002 \mu \mathrm{g}$.). Groen, Kamminga, Willebrands, and Blickman (4) assayed insulin by its effect on the glucose utilization of the isolated rat diaphragm. They presented evidence in rough agreement with Anderson, Linder, Sutton, and Bornstein as to the level of insulin in serum.

The biological methods do not measure insulin itself, but only its effects. Therefore, these assays are useful in measuring insulin in samples which do not contain any substances that affect glucose metabolism. Unfortunately, many tissues and biological fluids may contain substances, such as adrenaline and hormones of the adenohypophysis which do affect glucose metabolism. These methods also show considerable biological variation and require a large number of experimental procedures and statistical analysis to establish their validity and reliability.

The reliability of the immunological assay of insulin depends particularly upon the specificity of the antiserum. In the following paper (16) evidence is presented for the specificity of the rabbit antibodies for insulin itself, and for the immunological similarity of insulins from various species. Therefore, the hemolytic method employing rabbit antiserum to beef insulin is probably applicable to the measurement of insulin from various species.

The sensitivity of the immune hemolysis assay for insulin is dependent upon the dilution of antiserum employed. This is limited, because as the dilution of the antiserum increases, the curve becomes flattened and consequently the error greater. The assay of insulin by this method is also limited by a high non-specific lysis of erythrocytes. This non-specific lysis is dependent upon a heat labile substance in guinea pig serum which, in the presence of complement, causes the lysis of both nonsensitized and insulin-conjugated sheep erythrocytes. It appears that this substance is similar in 
many respects to properdin recently described by Pillemer and his associates (30). Studies on the removal of properdin from guinea pig serum with sheep erythrocyte stromata will be presented elsewhere (31). The effect of properdin on the hemolytic assay of proteins is being investigated.

It is not known at present whether the hemolytic assay will distinguish between physiologically active and inactive insulin. Also unknown is the applicability of the assay to the measurement of insulin in tissues and fluids.

\section{SUMMARY}

1. Methods are presented for the conjugation of insulin to sheep erythrocytes, with bis-diazobenzidine.

2. Antibodies to insulin can be consistently detected in rabbits using hemagglutination or hemolysis of the insulin-conjugated sheep erythrocytes as an end point.

3. Repeated intravenous injections of adequate amounts of alum-precipitated insulin over a sufficiently long period of time can consistently elicit antibodies to insulin in the rabbit.

4. Evidence is presented for the suggestion that the hemagglutination of insulin-conjugated erythrocytes by the sera of diabetic patients may be of value for future study of the immunological aspects of insulin resistance.

5. Methods are presented for the assay of microgram quantities of insulin in pure solutions.

\section{ACKNOWLEDGMENTS}

The authors are very appreciative of the competent technical assistance of Catherine Jarchow and Eleanor Allen. They are also grateful to Dr. Arnold Lazarow for many stimulating comments in the course of these studies.

\section{REFERENCES}

1. Stavitsky, A. B., and Arquilla, E. R., Estimation of insulin and antibodies to insulin in vitro by hemagglutination and hemolysis of insulin-treated red cells and inhibition of these reactions. Federation Proc., 1953, 12, 461.

2. Anderson, E., Linder, E., and Sutton, V., A sensitive method for the assay of insulin in blood. Am. J. Physiol., 1947, 149, 350.

3. Bornstein, J. A., Technique for the assay of small quantities of insulin with alloxan diabetic, hypo- physectomized, and adrenalectomized rats. Australian J. Exper. Biol. \& M. Sc., 1950, 28, 87.

4. Groen, J., Kamminga, C. E., Willebrands, A. F., and Blickman, J. R., Evidence for the presence of insulin in blood serum. A method for an approximate determination of the insulin content of blood. J. Clin. Invest., 1952, 31, 97.

5. Boyden, S. V., The adsorption of proteins on erythrocytes treated with tannic acid and subsequent hemagglutination by antiprotein sera. J. Exper. Med., 1951, 93, 107.

6. Borduas, A. G., and Grabar, P., L'hemagglutination passive dans la recherche des anticorps antiproteiques. Ann. Inst. Pasteur, 1953, 84, 903.

7. Stavitsky, A. B., Micromethods for the study of proteins and antibodies I. Procedure and general applications of hemagglutination and hemagglutination-inhibition reactions with tannic acid and protein-treated red blood cells. J. Immunol., 1954, $72,360$.

8. Stavitsky, A. B., Micromethods for the study of proteins and antibodies II. Specific applications of hemagglutination and hemagglutination-inhibition reactions with tannic acid and protein-treated red blood cells. J. Immunol., 1954, 72, 368.

9. Peck, J. L., and Thomas, L., Studies on the hemolysis of human erythrocytes by homologous complement in the presence of tannic acid. Bull. Johns Hopkins Hosp., 1949, 84, 216.

10. Pressman, D., Campbell, D. H., and Pauling, L., The agglutination of intact azo-erythrocytes by anti-sera homologous to the attached groups. J. Immunol., 1942, 44, 101.

11. Barral, P., and Roux, J., L'insuline constitute-t-elle en elle-même un antigène spécifique? Compt. rend. Soc. de biol., 1931, 106, 292.

12. Bernstein, C., Jr., Kirsner, J. B., and Turner, W. J., Studies on anaphylaxis with insulin. J. Lab. \& Clin. Med., 1938, 23, 938.

13. Lewis, J. H., Antigenic properties of insulin, J. A. M. A., 1937, 108, 1336.

14. Wasserman, P., Broh-Kahn, R. H., and Mirsky, I. A., The antigenic property of insulin. J. Immunol., 1940, 38, 213.

15. Lowell, F. C., and Franklin, W., Induced insulin resistance in the rabbit. J. Clin. Invest., 1949, 28, 199.

16. Arquilla, E. R., and Stavitsky, A. B., Evidence for the insulin-directed specificity of rabbit anti-insulin serum. J. Clin. Invest., 1956, 35, 467.

17. Kabat, E. A., and Mayer, N. M., Experimental Immunochemistry. Springfield, Ill., Charles C Thomas, 1948, p. 489.

18. Bukantz, S. C., Rein, C. R., and Kent, J. R., Studies in complement fixation. II. Preservation of sheep's blood in citrate dextrose mixture (modified Alsever's solution) for use in the complement fixation reaction. J. Lab. \& Clin. Med., 1946, 31, 394. 
19. Stavitsky, A. B., and Arquilla, E. R., Micromethods for the study of proteins and antibodies. III. Procedure and applications of hemagglutination and hemagglutination-inhibition reactions with bisdiazotized benzidine and protein-conjugated red blood cells. J. Immunol., 1955, 74, 306.

20. Lowry, O. H., and Bessey, O. A., The adaptation of the Beckman spectrophotometer to measurement on minute quantities of biological material. J. Biol. Chem., 1946, 163, 633.

21. Boyd, W. C., Fundamentals of Immunology. New York, Interscience Publishers, 1947, p. 421.

22. Nicol, J. C., and Deutsch, A. F., Biophysical studies of blood plasma proteins. VII. Separation of $\boldsymbol{\gamma}$-globulin from the sera of various animals. $J$. Am. Chem. Soc., 1948, 70, 80.

23. Franklin, W., and Lowell, F. C., Experimentally induced insulin resistance and allergy in the rabbit. J. Allergy, 1949, 20, 400.

24. Wasserman, P., and Mirsky, I. A., Immunological identity of insulin from various species. Endocrinology, 1942, 31, 115.

25. Berne, R. M., and Wallerstein, R. S., The role of antibodies in insulin resistance. Report of a case. J. Mt. Sinai Hosp., 1950, 17, 102.
26. Moloney, P. J., and Coval, M., Antigenicity of insulin : Diabetes induced by specific antibodies. Biochem. J., 1955, 59, 179.

27. Sehon, A. H., Kaye, M., McGarry, E., and Rose, B., Localization of an insulin-neutralizing factor by zone electrophoresis in a serum of an insulin-resistant patient. J. Lab. \& Clin. Med., 1955, 45, 765.

28. Lowell, F. C., Immunologic studies in insulin resistance. III. Measurement of an insulin antagonist in the serum of an insulin-resistant patient by the blood sugar curve method in mice. J. Clin. Invest., 1947, 26, 57.

29. Marsh, J. B., and Haugaard, N., The effect of serum from insulin-resistant cases on the combination of insulin with the rat diaphragm. J. Clin. Invest., 1952, 31, 107.

30. Pillemer, L., Blum, L., Lepow, I., Ross, O. A., Todd, E. W., and Wardlaw, A. C., The properdin system and immunity, I. Demonstration and isolation of a new serum protein, properdin, and its role in immune phenomena. Science, 1954, 120, 279.

31. Arquilla, E. R., and Allen, E., Removal of properdin from guinea pig serum with sheep erythrocyte stroma. To be published.

\section{SPECIAL NOTICE TO SUBSCRIBERS}

Post Offices will no longer forward the Journal when you move.

Please notify The Journal of Clinical Investigation, Business Office, 622 West 168th Street, New York 32, N. Y. at once when you have a change of address, and do not omit the zone number if there is one. 